\title{
Journal of Applied Pharmaceutical Science
}

Available online at www.japsonline.com

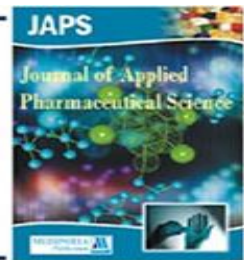

ISSN: 2231-3354

Received on: 24-07-2012

Revised on: 08-08-2012

Accepted on: 19-08-2012

DO: 10.7324/J APS.2012.2835
Egharevba Henry Omoregie KunleFolashade Ouyemisi, Okogun J oseph I bumeh

Department of M edicinal Plant Research and Traditional Medicine National Institutefor Pharmaceutical Research \&Development (NIPRD), I du I ndustrial Layout, I du, P.M.B. 21 Garki, Abuja, Nigria.

\section{Okwute Simon Koma} Department of Chemistry, Uni versi ty of A buja, Gwagwalada, FCT, Nigria

\section{For Correspondence} Egharevba Henry Omoregie Department of M edicinal Plant Research and Traditional M edicine National I nstitutefor P harmaceutical Research \& Development ( NIPRD) , I du I ndustrial Layout, I du, P.M.B. 21 Garki , Abuja, Nigeria.

Td: +234-805-155-9005

\section{Chemical Constituents of the Essential Oil of Laggera pterodonta (DC) Sch Bip From North-Central Nigeria}

\section{Egharevba Henry Omoregie, KunleFolashadeOluyemisi, OkwuteSimon Koma and Okogun J oseph I bumeh}

\begin{abstract}
The aerial part of Laggera pterodonta plant found in North-Central part of Nigeria was hydrodistilled and the volatile oil subjected to GCMS analysis. 23 components were identified in the essential oil of which n-Triacontane was the major constituent $(\sim 3 \%)$. Other major volatile constituents include, Dimethoxydurene ( 9\%), Caryophyllene oxide ( 7\%), Linoleoyl chloride ( 7\%), oleic acid ( 4\%), gamma-Eudesmol ( 4\%), 2,6,10-trimethylundeca-1,3, diene ( 3\%) and $\mathrm{n}$-Dotriacontane $(\sim 3 \%)$. This is the first time that $\mathrm{n}$-triacontane is being found as the major constituent of an essential oil, and also the first time the composition of the essential oil of Laggera pterodonta from North-central Nigeria is being reported.
\end{abstract}

Keywords: Laggera pterodonta, essential oil, chemical composition, n-triacontane, 2,6,10trimethylundeca-1,3,diene, 7-methyl-1-undecene, gamma-Eudesmol.

\section{INTRODUCTION}

Laggera pterodonta is annual shrub found growing as common weed in Nigeria. It belongs to the family Asteraceae (Compositae) and the genus consists of about 20 species. The plant is spread throughout the sub-Saharan Africa and the tropical countries of Asia, especially Southeast Asia, in open waste spaces and partially shaded galleried forest. It grows in Senegal, Sierra Leone, Nigeria and West Cameroons, and probably occurring elsewhere in the region (Burkill, 1985; Wu et al., 2011). Reports of chemical constituents of the volatile oil from the species in Benin and Cameroon as well as other regions showed variation in composition (Egharevba et al., 2010; Asfaw et al., 2001; Asfaw et al., 1999). The essential oil from the plant had been reported for use as an insecticide in Cameroon (Njan Nlôga et al., 2007; Ngamo et al., 2007). Despite the huge potential of the plant and its essential oil, it remained highly under-studied in Nigeria. The aim of this study was to examine the chemical constituents of the essential oil of the Nigerian species of the plant from North-central part of Nigeria with a view to establish the chemotype and usefulness. 


\section{MATERIALS AND METHODS}

All the solvents and reagents used in the study were of Analar grade and, unless otherwise stated, were sourced from Zayo-Sigma, Abuja, Nigeria.

\section{Collection and Extraction of Plant Material}

The plant (aerial part) was collected on the 15 November, 2009 from Chaza village, Suleja, Niger State, North-central zone of Nigeria, and authenticated by the Taxonomist in the Department of Medicinal Plant Research and Traditional Medicine of the National Institute for Pharmaceutical Research and Development (NIPRD) Abuja, Nigeria. The plant was assigned a voucher specimen number NIPRD/H/6403. The roots were removed and the fresh aerial parts were rinsed in distilled water and immediately used for the study.

\section{Hydrodistillation}

$500 \mathrm{~g}$ of fresh material was chopped to size with a clean kitchen knife and hydrodistilled over 5hrs using Clevenger apparatus. The oil/water mixture was collected into a glass sample bottle. The mixture was salted with $3 \mathrm{~g}$ of sodium chloride salt and then extracted with hexane. The moisture in the hexane extract was removed with $2 \mathrm{~g}$ of anhydrous sodium sulphate and filtered. The hexane filtrate was collected in a glass bottle and subjected to GCMS analysis.

\section{GCMS Analysis}

The oil was analysed on a Shimadzu GCMS-QP2010 Plus (Japan) at the National Research Institute for Chemical Technology (NARICT) Zaria, Nigeria. The column length, diameter and thickness were $30 \mathrm{~m}, 0.25 \mathrm{~mm}$ and $0.25 \mu \mathrm{m}$ respectively, and the stationary phase was $100 \%$ dimethylpolysiloxane. The conditions for analysis were set as follows; column oven temperature was programmed from $60-280^{\circ} \mathrm{C}$ (temperature at $60^{\circ} \mathrm{C}$ was held for $5 \mathrm{~min}$, raised to $140^{\circ} \mathrm{C}$ at $5^{\circ} \mathrm{C} / \mathrm{min}$ and then finally to $280^{\circ} \mathrm{C}$ at $15^{\circ} \mathrm{C} / \mathrm{min}$ and held for $10 \mathrm{~min}$ ); injection mode, Split (1.0); injection temperature, $250^{\circ} \mathrm{C}$; flow control mode, linear velocity $(46.3 \mathrm{~cm} / \mathrm{sec})$; pressure, $100.2 \mathrm{kPa}$; carrier gas, helium; total flow rate, $6.2 \mathrm{~mL} / \mathrm{min}$; column flow rate, $1.61 \mathrm{~mL} / \mathrm{min}$; ion source temperature, $200^{\circ} \mathrm{C}$; interface temperature, $250^{\circ} \mathrm{C}$; solvent cut time, $2.50 \mathrm{~min}$; start time $3.00 \mathrm{~min}$; end time, $35.00 \mathrm{~min}$; start $\mathrm{m} / \mathrm{z}$, 40 and end $\mathrm{m} / \mathrm{z}, 400$.

\section{RESULTS AND DISCUSSION}

Table 1 shows the GCMS data and the identified constituents of the hydrodistilled essential oil. The identification of the constituents was based on comparison of their mass spectra data with those available in the data bank of NIST library. The oil extraction yield was $0.001 \% \mathrm{v} / \mathrm{w}$.

The major component of the essential oil was ntriacontane which constituted $43.18 \%$ of the identified components. n- Dotriacontane has been previously reported from Laggera aurita, while other volatiles like sabinene, p-cymene, gamma-eudesmol were previously reported from the Cameroonian species of the plant (Ngassoum et al., 2000). 2,5-dimethoxy-pcymene (30.5\%) and gamma-eudesmol (24.6\% ) have been reported in the oil from the plant species in Benin Republic, while 2,5-dimethoxy-p-cymene (44.2\%) and sabinene (15\%) has been reported in L. alata (L. aurita) from Nigeria (Asfaw et al., 1999; Ekundayo et al., 1989). Previously reported compounds like thymol, Juniper camphor, $\delta$-cadinene, $\alpha$-cadinol, dimethoxy-pcymene isomers, laggerol, chrysanthenone isomers, isogeranic acid, isointennedeol, filifolone were not detected. Triacontane (Fig. 1) is a high molecular weight alkane with a melting point of $65-67^{\circ} \mathrm{C}$, boiling point of $449-451^{\circ} \mathrm{C}$ at $760 \mathrm{mmHg}$ and a flash point of $302.22^{\circ} \mathrm{C}$. The presence of volatile components like sabinene, cymene and terpineol (Fig. 1) suggests that the oil may be useful in aromatherapy and in the pharmaceutical and confectionary industries as fragrance or additives (Evans, 2002). Cymene has been reported to exhibit antibacterial properties, while caryophellene has been reported to exhibit antibacterial, antitumor, anti-inflammatory and antifungal properties (Sulochana and Bakiyalakshmi, 2011). Other components like diisooctyl adipate and linoleoyl chloride (Fig. 1) are used in the synthesis of a number of organic polymers (Evans, 2002).

\section{CHEMICAL STRUCTURES OF IDENTIFIED COMPOUNDS}

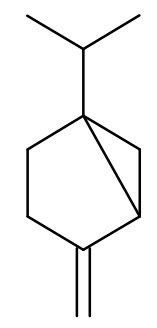

Sabinene

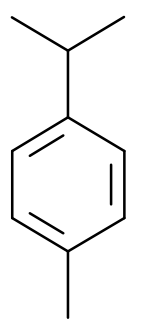

p-Cymene

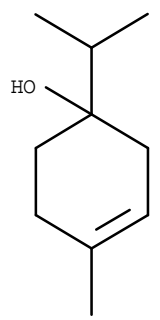

4-Terpineol

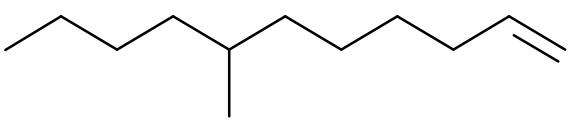

7-Methyl-1-undecene

Fig. 1: Continued.... 


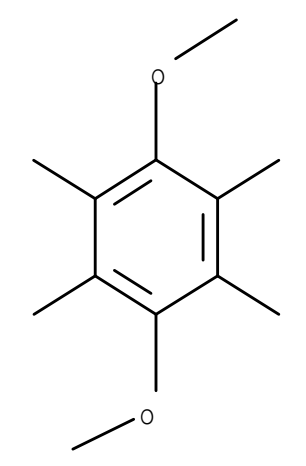

Dimethoxydurene

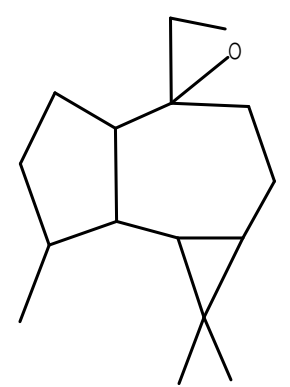

Alloaromadendrene oxide

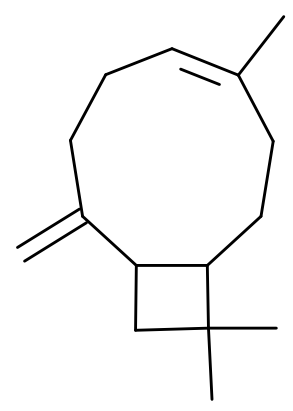

Caryophyllene

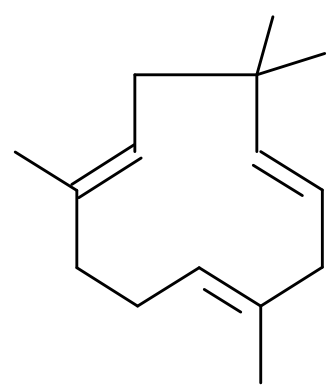

Humulene

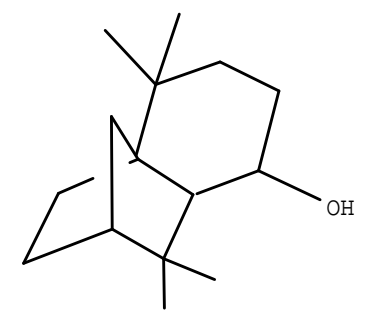

Isolongifolan-8-ol

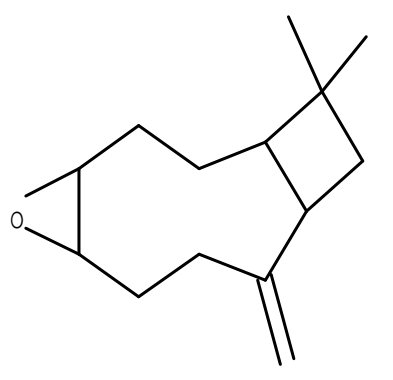

Caryophyllene oxide<smiles>CC1=C2CC(C(C)(C)O)CCC2(C)CCC1</smiles>

gamma-Eudesmol

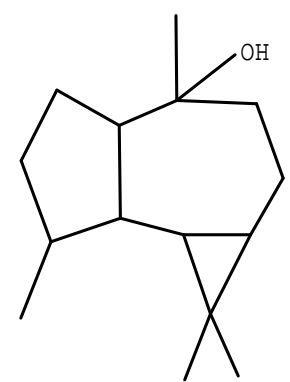

Viridiflorol<smiles>C=C(C)/C=C/CC(C)CCCC(C)C</smiles>

2, 6, 10-trimethylundeca-1,3, diene<smiles>C=C(OC(C)C)c1ccccc1C(=O)OCC(C)C</smiles><smiles>C=C(O)CCCCCCCCCCCCCCC</smiles>

Diisobutyl phthalate

Fig. 1: Continued.... 

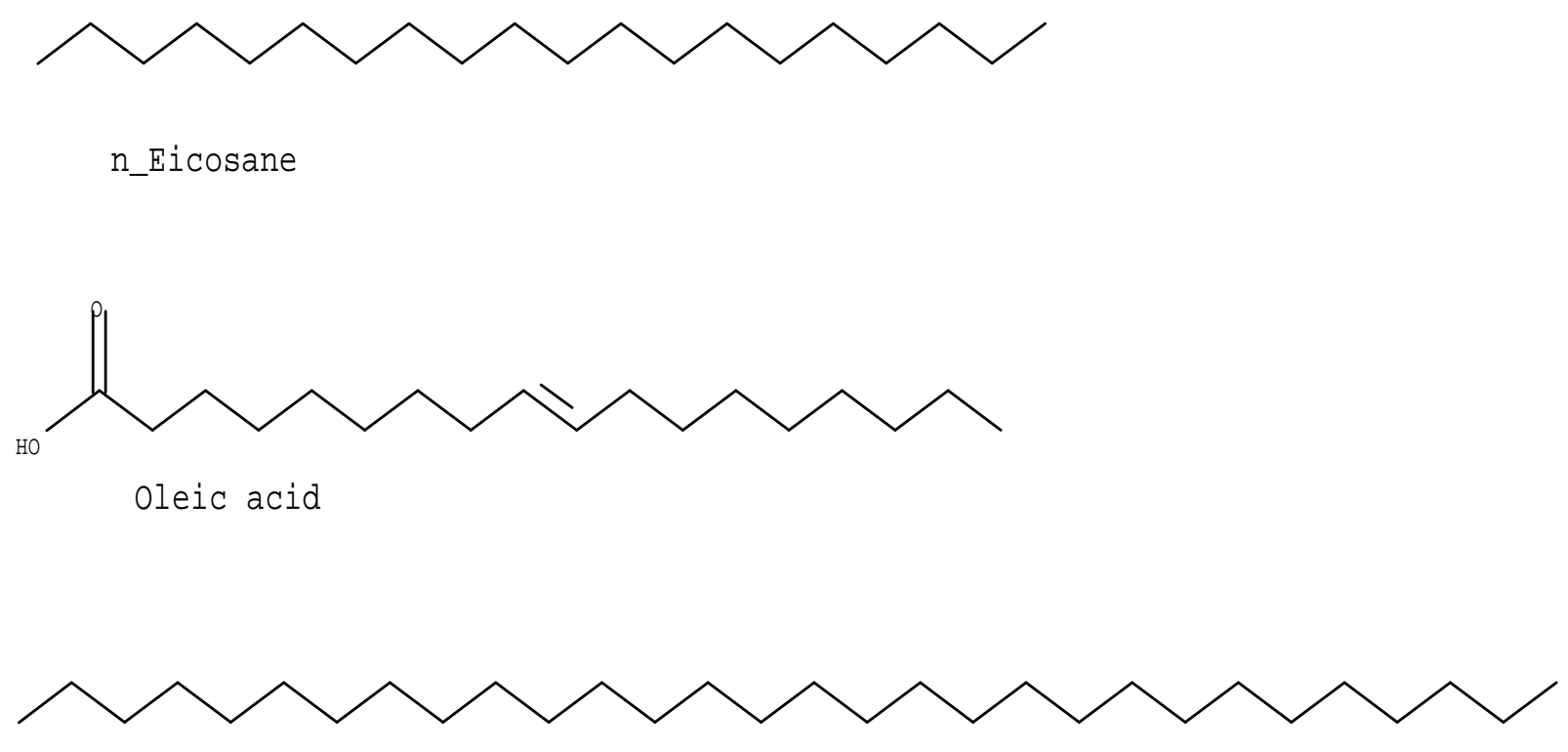

n-Triacontane
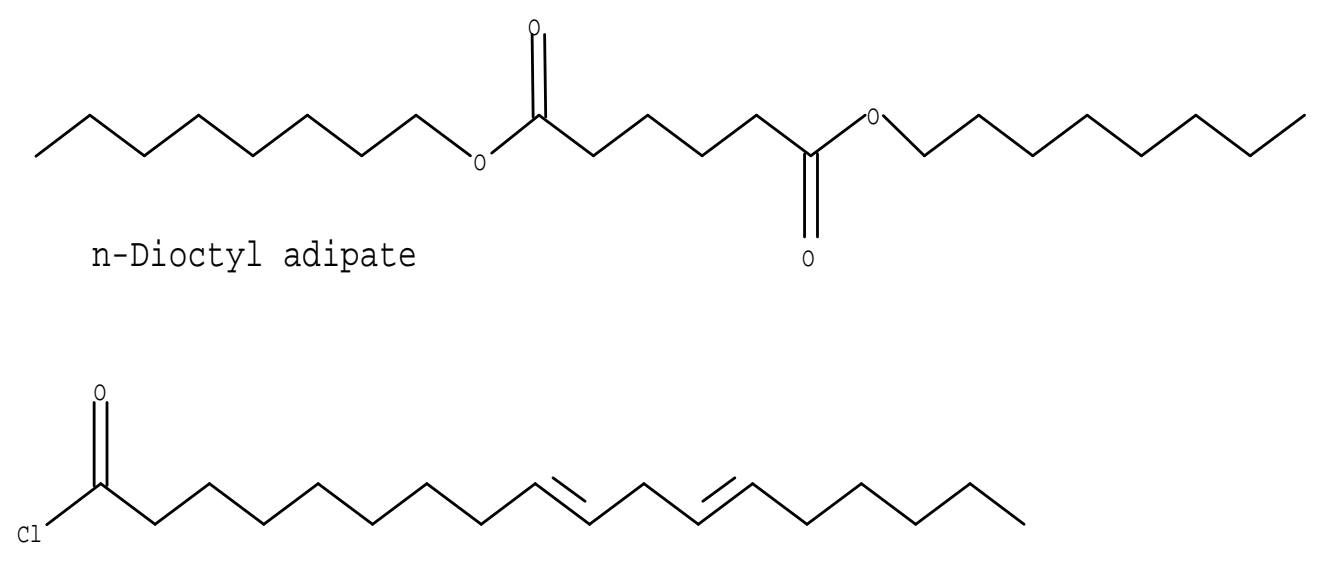

Linoleoyl Chloride

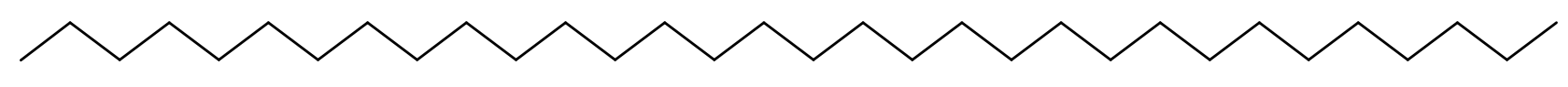

n-Dotriacontane<smiles>CC(C)=CCC/C(C)=C/CC/C(C)=C/CC/C=C(\C)CC/C=C(\C)CCC=C(C)C</smiles>

Fig. 1: Chemical structures of identified compounds. 
Table. 1: Gcms Analysis of Essential oil of Laggera Pterodonta.

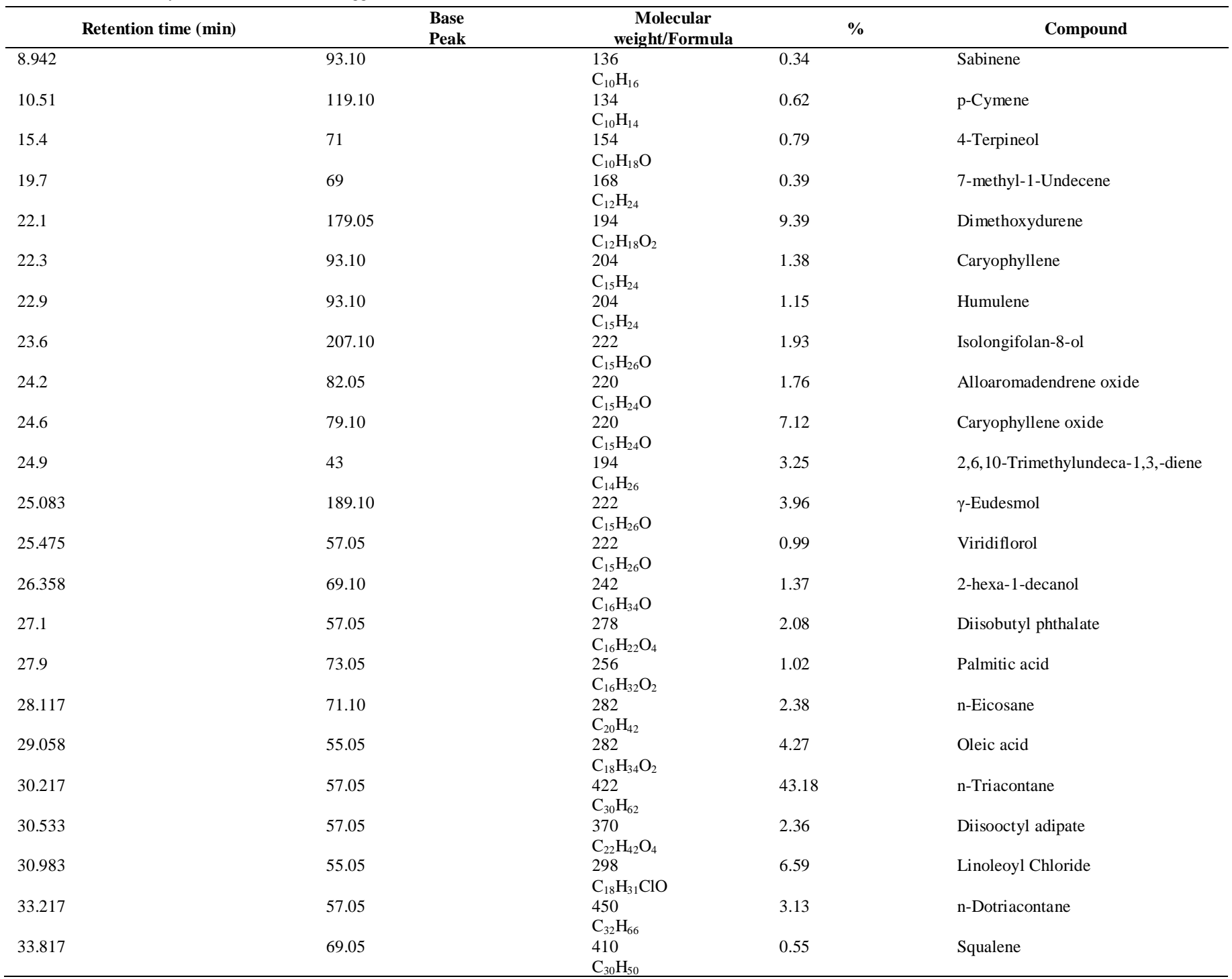

\section{CONCLUSION}

The major essential oil chemotype for $L$. Pterodonta in the African region include oxygenated sesquiterpenoid-rich oil like those rich in p-cymene $(30.5,44.2 \%)$, and hydrocarbon-rich oil such as n-triacontane-rich as found in this study (43.18\%). This is the first time the composition of essential oil has been found to contain this high level of n-triacontane. It is also the first time ntriacontane, 7-methyl-1-undecene, dimethoxydurene, isolongifolan -8-ol, 2,6,10-trimethylundeca-1,3, diene, viridiflorol, 2-hexyl-1decanol, diisobutyl phthalate, alloaromadendrene oxide, caryophellene oxide, palmitic acid, oleic acid, n-eicosane, dioctyl adipate, linoleoyl chloride and squalene were being reported from the volatile oil of Laggera species especially L. pterodonta. The marked difference in chemical composition of the essential oil of L. pterodonta in this study from those previously reported by other workers may be due to variation in geo-ecological factors such as soil type, vegetation and humidity, as well as genetic factors (Owolabi et al., 2009).

\section{ACKNOWLEDGEMENT}

The publication was taken from the thesis submitted to the University of Abuja, Nigeria, for the purpose of an award of the degree. The authors are grateful to the management of the National Institute for Pharmaceutical Research and Development (NIPRD) and staff of the Department of Medicinal Plant Research and Traditional Medicine for their supports.

\section{REFERENCES}

Asfaw N, Staresund HJ, Skattebol L, Aasen AJ. (1S,5R)-(-)2,4,4-Trimethylbicyclo [3.1.1]hept-2-en-6-one, from the essential oil of the Ethiopian plant Laggera tomentosa. Phytochem., 1999; 52: 1491-1494

Asfaw N, Staresund HJ, Skattebol L, Aasen AJ. Coexistence of chrysanthenone, filifolone and (Z)-isogeranic acid in the hydrodistillates Artefacts. Phytochem., 2001; 58: 489-492.

Burkill HM. The Useful Plants of West Tropical Africal. Vol. 1, Families A-D. Royal Botanic Gardens Kew, (1985) 479-481

Egharevba HO, Abdullahi MS, Okwute SK, Okogun JI. Phytochemical Analysis and Broad Spectrum Antimicrobial Activity of 
Laggera pterodonta (DC.) Sch. Bip. (Aerial Part). Researcher, 2010; 2(10):35-40

Ekundayo O, Oguntimein B, Laakso I, Hiltunen R. Composition of the essential oil of Laggera alata. Planta Med. 1989; 55, 573-574.

Evans WC. Trease and Evans Pharmacognocy. $15^{\text {th }}$ Edition, Elsevier India, (2002) 3-554.

Ngamo TSL, Ngassoum MB, Mapongmestsem PM, Noudjou WF, Malaisse F, Haubruge E, Lognay G, Kouninki H, Hance T. Uses of Essential Oils of Aromatic Plants as Protectant of Grains During Storage. Agric J. 2007; 2(2): 204-209.

Ngassoum MB, Jirovetz L, Buchbauer G, Fleischhacker W. Investigation of the essential oil and headspace of Laggera pterodonta (DC.) Sch. Bip. ex Olive., a medicinal plant from Cameroon. J. Ess. Oil Res., 2000; 12: 345-49.
Njan Nlôga AM, Saotoing P, Tchouankeu JC, Messi J. Effect of Essential Oils of Six Local Plants Used Insecticide on Adults of Anopheles gambiae, Giles 1902. J. Entomol., 2007; 4 (6):444-450.

Owolabi MS, Ogundajo A, Lajide L, Oladimeji MO, Setzer WN, Palazzo MC. Chemical Composition and Antibacterial Activity of the Essential oil of Lippia multiflora Mondenke from Nigeria. Rec. Nat. Prod. 2009; 3(4): 170-177.

Sulochana S, Bakiyalakshmi SV. Effect of neutraceutical dosa on antimicrobial activity. Int'1 J. Env. Sci. 2011; 1(5): 727-735.

Wu Y, Wang F, Zheng Q, Lu L, Yao H, Zhou C, Wu X, Zhao Y. Hepatoprotective effect of total flavonoids from Laggera alata against carbon tetrachloride-induced injury in primary cultured neonatal rat hepatocytes and in rats with hepatic damage. J. Biomed. Sci., 2006; 13: 569-578. 